\title{
$>$ Pessimism and monstrosity: a comparative analysis between Frankenstein and The Hunger Games
}

\author{
$>$ Pessimismo e monstruosidade: \\ uma análise comparativa entre Frankenstein e Jogos vorazes
}

\begin{abstract}
por Andressa Carolina dos Santos Benedito
Graduanda no curso de Letras - Inglês da Universidade Estadual do Paraná - Campus de Apucarana (UNESPAR). E-mail: carolinaaandressa@hotmail.com. ORCID: 0000-0002-9215-1994.
\end{abstract}

\section{Por Fernanda Martinez Tarran}

Doutoranda em Estudos Literários na linha de pesquisa Literatura Comparada do Programa de PósGraduação em Letras da Universidade Estadual de Londrina (UEL). E-mail: fertarran@hotmail.com. ORCID: 0000-0001-8802-8419.

\begin{abstract}
This research intends to demonstrate the pessimistic perspective regarding technological and scientific progress in the trilogy The Hunger Games, by Suzanne Collins. We start from the analysis of some elements in Frankenstein, by Mary Shelley, one of the first science-fiction novels. We are grounded on theoretical writings of authors that shared the same pessimistic point of view. Furthermore, this article investigates the faces of monstrosity in the trilogy The Hunger Games, and takes into account, albeit to a lesser extent, the contrast with the creature created by Victor Frankenstein. Our objective, despite the focus on Collins' trilogy, is to show how these narratives, written with an interval of almost two hundred years, converge into the same questioning about the future.
\end{abstract}

Keywords: Science-fiction. Dystopia. Progress. Pessimism. Monstrosity.

\section{Resumo}

Este trabalho pretende assinalar a visão pessimista quanto ao progresso tecnológico e científico presente na trilogia contemporânea Jogos Vorazes, de Suzanne Collins. Partimos da análise de alguns elementos da obra consagrada Frankenstein, de Mary Shelley, um dos primeiros romances do gênero da ficção científica. Apoiamo-nos na teoria de pensadores que escreveram sobre a mesma visão pessimista. Ademais, nossa pesquisa investiga as faces da monstruosidade na trilogia Jogos Vorazes, levando em conta, ainda que em menor medida, o contraste com a criatura gerada por Frankenstein, categorizada como monstro clássico. Nosso objetivo, em que pese a ênfase na obra mais recente, é o de mostrar como essas histórias, separadas por quase duzentos anos, convergem para o mesmo questionamento sobre o futuro.

Palavras-chave: Artigo recebido Ficção científica. Distopia. Progresso. Pessimismo. 


\section{Introduction}

Ursula K. Le Guin, an important name of American science fiction literature, defined the genre as a kind of metaphor:

[w] hat sets it apart from older forms of fiction seems to be its use of new metaphors, drawn from certain great dominants of our contemporary life -science, all the sciences and technology, and the relativistic and the historical outlook, among them ${ }^{1}$.

Nowadays, science fiction is wildly known in the entertainment universe, yet the genre might have its roots in the gothic novel Frankenstein, written by Mary Shelley and first printed in 1818.

The story of Frankenstein portrays Victor Frankenstein's ambition to discover the secrets of nature, death and creation. In the character's own words, his desire was to learn "the physical secrets of the world"2. After succeeding in his mission of "infus[ing] a spark of being into the lifeless thing" ${ }^{3}$, Victor almost immediately regretted his doing. He was "unable to endure the aspect of the being"4 he had just created.

The importance and the pioneering of Shelley's novel is defended by Brian Aldiss through the first chapter of his book Billion Year Spree: The True History of Science Fiction. He refers to Frankenstein as "the first real novel of science fiction: Frankenstein is the modern theme, touching not only science but man's dual

\footnotetext{
${ }^{1}$ Ursula K. Le Guin, "Introduction", 2010, p. XI.

${ }^{2}$ Mary Shelly, Frankenstein, 2015, p. 25.

${ }^{3}$ Ibidem, p. 44.

${ }^{4}$ Ibidem, p. 44.
} 
nature, whose inherited ape curiosity has brought him both success and misery"

Shelley's novel explores the power of science and also the threatening effect it can have over society. The writer brings up questions still without an answer today. For example: what are the ethical boundaries of science? Also, how far can we go without creating something that may destroy all of us?

The two World Wars proved how technological and scientific advances can be used to maximize conflicts and cause destruction on a scale never seen before in human history. These events changed human relations and also had an impact in the way people look at things. Thoughts on these consequences (especially pessimistic ones) can be found in Hannah Arendt and Walter Benjamin theoretical works, which we will soon discuss. Both authors were Jews who were born in Germany and whose lives were strongly affected by the war context.

Dystopias are one of the subgenres of science fiction, born from the negative perspective on scientific and technological evolution. They portray society as something "characterized by human misery, squalor, oppression, disease, and overcrowding"6.

In a parallel to Mary Shelley's work, we are going to analyze Suzanne Collins dystopia The Hunger Games. In the trilogy, the protagonist Katniss Everdeen lives in a world named Panem, built after a war that almost wiped out

\footnotetext{
${ }^{5}$ Brian Aldiss, Billion year spree: the true history of science fiction, 1973, p. 29.

${ }^{6}$ Keshia McClantoc, Welcome to the Arena, 2016, p. 510.
} 
humanity. Panem is formed by thirteen districts and governed by the central region, called the Capitol. Each district provides a commodity. District Twelve (one of the poorest), our protagonist's district, is responsible for the country's coal production.

Up until the Dark Days, District Thirteen was in charge of nuclear weaponry. The Dark Days is the term used throughout the novels to refer to the first districts' rebellion against the Capitol. The Dark Days resulted in many deaths. District Thirteen was firebombed to the ground in retaliation when the Capitol won the dispute and established itself in the frames of a one-man leadership ruled by President Snow.

As a reminder of the consequences of going against the Capitol, The Hunger Games were created. Before the start of the Games - as payment to the Capitol and acknowledgment of the districts' submission -, a male and a female human tribute of each district would be selected to fight until death inside a nonescape arena. The tributes would have to be aged between twelve and eighteen years old, and the victor of the Games would be the last one standing.

Katniss Everdeen volunteers to be her district's female tribute of the Seventy-fourth edition of The Hunger Games to save her little sister, whose name was the one originally selected. Peeta Mellark is nominated as the district's male tribute. The Games' Seventy-fourth edition, because of Katniss' inquiring and challenging personality — and her wish to keep Peeta and herself alive - become the spark to a second rebellion. 
In the following pages, we are going to make a comparative analysis of Frankenstein pioneering scientific pessimism and the possible consequences of such both technological and scientific evolution in the dystopian world of The Hunger Games trilogy. We will also discuss how monsters were presented in both stories. To support this analysis, we are going to use Hannah Arendt and Walter Benjamin's theoretical works, as well as Michelle Kay Hansen's dissertation on monsters.

\section{Progress and pessimism}

Using a piece of art as inspiration, Walter Benjamin talks about Catastrophe piling up rubble before the Angel of History's feet. ${ }^{7}$ Catastrophe, according to him, is what we call progress. Progress reappears in Benjamin's metaphor in the form of a storm that keeps pushing the Angel irresistibly towards the future, and it does the same with humanity, while the pile of rubble continues to grow sky-high. This metaphor can be interpreted as a direct criticism regarding the idea of progress and a firm pessimistic concern about its effects. $^{8}$

Throughout the nineteenth century, expressive progress took place in development of lighting technologies. ${ }^{9}$ Consequences of this fact can be seen in Mary Shelley's Frankenstein, as for the light has great symbolism and presence in

\footnotetext{
${ }^{7}$ Walter Benjamin, "Sobre o conceito de história", 1985, p. 225-226.

${ }^{8}$ Ibidem, p. 226.

${ }^{9}$ William D. Nordhaus, The Economics of New Goods, 1996, p. 34.
} 
the novel: "What may not be expected in a country of eternal light?"10. Actually, it is with a flash of light that Victor Frankenstein discovers the secret of nature that made it possible for him to give life to his creature.

However, Walter Benjamin ${ }^{11}$ believed that advances in the exploration of nature led to technocratic values-those resulting of the belief that many societal problems are solvable with the applied use of technology. These values can be found in supreme authority regimes. Therefore, these advances can be some of the reasons for society's regression, from his point of view. ${ }^{12}$

The Hunger Games trilogy, as explained above, is set on a dystopian future were science and technology are in a more advanced stage than that of the twenty-first century - and even more advanced when compared to Victor Frankenstein's world. Electric power was only the first of several technological innovations that would surround people's lifestyle. We are now going to examine some of the key tactics- mainly based in technological and scientific progress that the total authority rulership of Panem, run by the Capitol, uses to control the districts and to remain in the country's political command.

In the next passage, we can see Katniss' reaction when she is faced with the reality of District Eleven and when she realizes the intensity of the power enforcement over its inhabitants:

[...] a fence rises up before us. Towering at least thirty-five feet in the air and topped with wicked coils of barbed wire [...]. My eyes quickly inspect

\footnotetext{
${ }^{10}$ Mary Shelley, Op. Cit., 2015, p. 2.

${ }^{11}$ Walter Benjamin, Op. Cit., 1985, p. 227-228.

${ }^{12}$ Ibidem, p. 227-228.
} 
the base, which is lined with enormous metal plates. There would be no burrowing under those, no escaping to hunt. Then I see the watchtowers, placed evenly apart, manned with armed guards, so out of place among the fields of wildflowers around then. ${ }^{13}$

District Eleven is the one responsible for agriculture. Consequently, it is in charge of the food that is sent to the Capitol. In spite of this, according to Rue (the female tribute of District Eleven for the Seventy-fourth edition of the Hunger Games), the inhabitants of her district do not have access to the food they cultivate. They can only eat the small percentage designated to them by the Capitol, with death as penalty for those who try to have more.

These methods of government placed over the districts correlate with Hannah Arendt's statement on terror in her book The Origins of Totalitarianism, where she announces terror as the very essence of supreme authority governments. The author states that "[t]error continues to be used by totalitarian regimes even when its psychological aims are achieved: its real horror is that it reigns over a completely subdued population" ${ }^{14}$. For the Capitol, another method of assurance of its repression over the already subdued people from the districts is, noticeably, the Hunger Games. So, it is accurate to affirm that the Capitol ruled by terror.

Furthermore, Arendt writes about the influences of supreme governments' propaganda. The author states that "the masses have to be won by propaganda"15 for the establishment of this kind of government, but it no longer

\footnotetext{
${ }^{13}$ Suzanne Collins, Catching Fire, 2009, p. 52.

${ }^{14}$ Hannah Arendt, The Origins of Totalitarianism, 1973, p. 344.

${ }^{15}$ Ibidem, p. 341.
} 
needs that resource afterwards. This is not the case in Collins' dystopian world, as the Capitol continually displays propaganda and even a cruel reality showthat serves as a way of amusement for the people who live in the Capitol and as punishment for those in the districts. Regarding this, Kavadlo declares:

The name Panem comes from the Roman expression "panem et circenses", or "bread and circuses": that is, if the poor are given enough to subsist on and a healthy distraction from their own penury, they will not rise against the system - or if the poor are kept struggling, they will not have the strength to rebel even if they wanted to. ${ }^{16}$

Katniss also comes to the conclusion that the districts are responsible for producing "bread and circuses" 17 to the Capitol. They are the ones who provide all that is needed and more to maintain the Capitol's luxury parties and extravagances. They are the poor who are kept struggling, even starving, in some cases, to prevent the rise of a second rebellion. Meanwhile, the people from the Capitol are amused by their fighting for survival; they feast at big parties and even vomit so they are able to keep feasting - as we can see in the following excerpt:

All I can think of is the emaciated bodies of the children on our kitchen table as my mother prescribes what the parents can't give. More food. Now that we're rich, she'll send some home with them. But often in the old days, there was nothing to give and the child was past saving, anyway. And here in the Capitol they're vomiting for the pleasure of filling their bellies again and again. Not from some illness of body or mind, not from spoiled food. It's what everyone does at a party. Expected. Part of the fun. ${ }^{18}$

\footnotetext{
${ }^{16}$ Jesse Kavadlo, American popular culture in the era of terror: falling skies, dark knights rising, and collapsing cultures, 2015, p. 141-142.

${ }^{17}$ Jesse Kavadlo, Op. Cit., 2015, p. 141.

${ }^{18}$ Suzanne Collins, Op. Cit., 2009, p. 75-76.
} 
Hence, besides forcing twenty-four years old tributes to fight to death every year on a television show to entertain the Capitol residents, the government also forces the districts to watch their kids being killed. And even after all of that, the survivor - or the victor, as they call it - has to come back to the Capitol and assist the new selected tributes as their mentor at each new edition of the Games. As a result, the cameras only leave the victors when they are dead.

In this subject, Walter Benjamin points out how the cinema, which he declares to be a consequence of the reproduction era, was used to spread absolute authority governments' ideologies to the masses. ${ }^{19}$ One more characteristic from his era stated by Benjamin is the desire of contemporary masses to get closer to things and knowing so, the film industry uses the masses curiosity in the movie stars' personal lives to increase the interest on the film industry itself. ${ }^{20}$

That is what happens to the Games' tributes and to the victors' lives, although they do not have any other choices but to keep playing the role expected from them. In the following quotation, we can see Haymitch Abernathy - Katniss and Peeta's mentor through the Seventy-fourth edition of the Hunger Games and the only other victor from District Twelve who is still alive - telling Katniss how the rest of her life is already delineated as a spin-off of the entertainment show for the Capitol:

You and Peeta, you'll be mentors now, every year from here on out. And every year they'll revisit the romance and broadcast the details of your

\footnotetext{
${ }^{19}$ Walter Benjamin, “A obra de arte na era de sua reprodutibilidade técnica”, 1985, p. 172.

${ }^{20}$ Ibidem, p. 185.
} 
private life, and you'll never, ever be able to do anything but to live happily ever after with that boy. ${ }^{21}$

However, the Capitol's distraction is built on human beings who live in a non-stopping state of suffering and are deprived of decent life conditions. Katniss' moves make sure that, for the first time, the Hunger Games have two victors instead of one - that is the spark to the start of the rebellion.

And, as a plot twist, the rebels seize one of the Capitol's resources to manipulate people's behavior and to keep the flames of the revolution alive: the power of the media. Over the trilogy's third book, the rebels use short films to incite the revolution. A battle for the control of what is going on air in the televisions of Panem is settled between them and the Capitol's technological specialists, as we can see in this passage:

\footnotetext{
"You're going to be as useful to the war effort as possible," Plutarch says, "And it's just been decided that you are of most value on television. Just look at the effect Katniss had running around in that Mockingjay suit. Turned the whole rebellion around. Do you notice how she's the only one not complaining? It's because she understands the power of that screen" ${ }^{22}$
}

It is clear that the power of the media is well-known by Katniss, since she understands how the Capitol used the curiosity of the public about the tributes' personal lives to increase the power that The Hunger Games had over their

\footnotetext{
${ }^{21}$ Suzanne Collins, Catching Fire, 2009, p. 41. 
society. After all, the Games are a television show intentionally propagating the essence of terror, a characteristic of President Snow's ultimate commandership.

The terror of this regime was made possible through monstrous actions allowed by the technological and scientific progress of Panem's dystopian world. And as a result, a pile of rubble composed of death and misery was set behind on the path of Collins' story - and also Shelley's (precisely, a pile of bodies of Frankenstein beloved ones and a gloomy journey towards revenge which was shortened by his own death) -, just as Walter Benjamin affirmed. ${ }^{23}$

Monstrosity is the keyword to follow our analysis. Since the wicked consequences of progress have already been established, we are now going to focus on who is behind the pursuit and application of those scientific and technological advances. Moreover, we are going to try to define monster and monstrosity and how they can be interpreted throughout Frankenstein and The Hunger Games trilogy.

\section{Monstrosity through progress}

Michelle Kay Hansen asserts, in the introduction of her dissertation on the monster subject, that " $\mathrm{t}]$ he more restrictive the definition of monster, the more confined one's definition of gothic and horror becomes"24. In her opinion, Noel Carroll's monster definition is one of those limited ones. For Carroll, monsters

\footnotetext{
${ }^{23}$ Walter Benjamin, "Sobre o conceito de história", 1985, p. 226.

${ }^{24}$ Michelle Kay Hansen, Monsters in our midst: an examination of human monstrosity in fiction and film of United States, 2009, p. 1.
} 
are "of either a supernatural or sci-fi origin" ${ }^{25}$, and therefore cannot be humans. This is similar to Victor Frankenstein' own explanation about monsters: "[n]othing in human shape could have destroyed the fair child. He was the murderer! I could not doubt it. The mere presence of the idea was an irresistible proof of the fact"26.

The quotation above translates Victor Frankenstein's thoughts after he realizes his creature had murdered his little brother. Victor's use of the word human is very interesting. He affirms such cruelty as killing an innocent child could not have been made by a human being. Only a monster, then, would be capable of such despicable act. Analogously, we can see the Capitol of Panem, governed by humans, harvesting innocent kids and forcing them to kill each other inside a non-escape arena once a year. On that matter, Katniss and Victor think differently, as she states:

I no longer feel any allegiance to these monsters called human beings, despite being one myself. I think that Peeta was onto something about us destroying one another and letting some decent species take over. Because something is significantly wrong with a creature that sacrifices its children's lives to settle its differences. ${ }^{27}$

Hence, besides including humans into her monsters' definition, Hansen analyzes the influence of social-historical events over the creation of monsters and consequently encompasses concepts like institutions into that definition in this case, we can count the Capitol's regime as one of those institutions viewed

\footnotetext{
${ }^{25}$ Noel Carroll, The philosophy of horror or paradoxes of the heart, 1990, p. 15.

${ }^{26}$ Mary Shelley, Op. Cit., 2015, p. 64.

${ }^{27}$ Suzanne Collins, Mockingjay, 2010, p. 377.
} 
as monsters. The scholar admits Carroll's acknowledgement of the socialhistorical influence over the appearances of monsters, although, in her own words, "he fails to consider how these influences have also changed the very definition of what makes a monster" ${ }^{28}$.

Back to The Hunger Games, the Capitol's high-technology allowed the Gamemakers - people responsible for planning the arenas and the Games as a whole - to intervene and manipulate the arena via a control room far away from the actual arena. They control its temperature and weather and, by doing so, they take away the power nature has of being uncontrollable and unpredictable. They revoke the naturalness of natural phenomena.

Again, the idea of humans playing god presents itself. Like Victor Frankenstein, who selected and manipulated corpses' body parts in order to form his own creature, the Gamemakers operated other parts of nature's natural order to reach their goals. For Hansen, when humans play god in stories like Frankenstein, there are usually terrible consequences and that should be a clue for the ultimate destruction technology can bring to people's lives. ${ }^{29}$

In The Hunger Games, the arenas are surrounded by a force field designed to keep the tributes inside and touching it can be fatal. The Seventy-fifth edition of the Hunger Games' arena is shaped like a round clock and operates as one. There are twelve sections - each one symbolizing a different hour of the clock — containing unique events (or horrors, as Katniss calls them). The clock starts working at midnight of the tributes' first day in the arena. After twelve bongs, an

\footnotetext{
${ }^{28}$ Michelle Kay Hansen, Op. Cit., 2009, p. 3.

${ }^{29}$ Michelle Kay Hansen, Op. Cit., 2009, p. 75.
} 
electrical lightning storm begins. Analogously, the beginning of Victor Frankenstein's curiosity towards electricity started with lightning:

When I was about fifteen years old we had retired to our house near Belrive, when we witnessed a most violent and terrible thunderstorm. It advanced from behind the mountains of Jura, and the thunder burst at once with frightful loudness from various quarters of the heavens. I remained, while the storm lasted, watching its progress with curiosity and delight. As I stood at the door, on a sudden I beheld a stream of fire issue from an old and beautiful oak which stood about twenty yards from our house; and so soon as the dazzling light vanished, the oak had disappeared, and nothing remained but a blasted stump. When we visited it the next morning, we found the tree shattered in a singular manner. It was not splintered by the shock, but entirely reduced to thin ribbons of wood. I never beheld anything so utterly destroyed. ${ }^{30}$

Back in the arena, the following hours are represented respectively by blood rain and chemical fog. The fog not only burns the skin but also affects the nerves, making it impossible for the tributes to have control over their own bodies. Chemistry is an important branch of science to Frankenstein's experiment and probably the key to his discovery of how to give life to a being. In fact, one of Frankenstein's teachers talks about Chemistry's potentiality to develop:

Chemistry is that branch of natural philosophy in which the greatest improvements have been and may be made; it is on that account that I have made it my peculiar study; but at the same time, I have not neglected the other branches of science. ${ }^{31}$

\footnotetext{
${ }^{30}$ Mary Shelley, Op. Cit., 2015, p. 28.

${ }^{31}$ Ibidem, p. 36.
} 
Collins, however, shows how this progress can be used to the very opposite of the primary purpose of Frankenstein's research: death. The third book of the trilogy follows the rebels trying to gain control over the Capitol after the districts were already taken over. Before Katniss goes to the Capitol, Plutarch Heavensbee - former Gamemaker who joins the rebels cause - shows the rebels a program revealing the Capitol's map with some marked points representing traps. These traps are called pods.

Pods were how the Gamemakers controlled the traps inside the arena and were designed to kill or incapacitate the tributes (as the ones used on the clock arena). Katniss and Finnick, another victor, recognize the nature of the pods, and come to the conclusion they are going to another arena - but, this time, the arena is the very Capitol.

As mentioned before, Katniss refers to these pods as horrors during her second time inside an arena. Following the ideas of other authors before her, like Ann Radcliffe ${ }^{32}$, Hansen differs terror - feeling of anxiety or dread near scary situations - from horror, which she believes to be a visceral reaction to horrifying events. Horror comes from witnessing cruelty beyond belief, like slavery. The author classifies slavery as a monster itself. Plus, the word horror can be found in documents made by slaves and former slaves, as Hansen points out. ${ }^{33}$

As previously mentioned, Hannah Arendt proclaims terror as the base of supreme authority regimes. For her, the brutal violence used over its submissive

\footnotetext{
${ }^{32}$ Ann Radcliffe, On the Supernatural in Poetry, 1826, p. 145-152.

${ }^{33}$ Michelle Kay Hansen, Op. Cit., 2009, p. 118-119.
} 
subjects is the real horror. ${ }^{34}$ We can see some similarities between Arendt's characterization of horror and Katniss' story. After all, the Capitol expects most of the tributes - and later the rebels - to be killed during a confrontation with one of their pods. The tributes, specially, did not have other choice but to be a part of their show and to deal with their horrifying traps.

Another tool used by the Capitol are genetically modified creatures called muttations or just mutts - that they use as weapons, most of them lethal. The mutts were used during the districts' first and second rebellions. Once inside the arenas, their main purpose is to maximize the amusement of the viewers from the Capitol. On the other side of our analysis, Frankenstein also did not have the intention of giving life to something lethal - even though, as we know, his creation ends up murdering his loved ones. In spite of the original intentions, both results are the same.

Shelley talks about the danger of mishandled knowledge through the Introduction for the 1831 edition of Frankenstein:

I saw -with shut eyes, but acute mental vision-I saw the pale student of unhallowed arts kneeling beside the thing he had put together. I saw the hideous phantasm of a man stretched out, and then, on the working of some powerful engine, show signs of life and stir with an uneasy, half-vital motion. Frightful must it be, for supremely frightful would be the effect of any human endeavor to mock the stupendous mechanism of the Creator of the world..$^{35}$

\footnotetext{
${ }^{34}$ Hannah Arendt, Op. Cit., 1973, p. 344.

${ }^{35}$ Mary Shelley, “Introduction”, 1831, p I.
} 
As we can see, Shelley herself believed that the use of technology by men and women could lead to a dangerous outcome.

Although people - like Victor Frankenstein - and institutions - like the Capitol - are not taken into account by Carroll on his descriptions of monsters, either Frankenstein's creature or the Capitol's evil creations would fully fit the author's definitions of the grotesque: "[t]hey are not only quite dangerous but they also make one's skin creep. Characters regard them not only with fear but with loathing, with a combination of terror and disgust" ${ }^{\prime 36}$. As we understand, the above mentioned creatures may not be the real monsters (as their creators probably are), but they assemble many of the features that Carroll considers to be typically monstrous: they are abnormal, aberrant, repulsive, deviant from the norm; when opposed to other characters, they cause horror and repugnance.

Almost in the end of the Seventy-fourth edition of the Hunger Games, the remaining tributes are forced to face wolf-like mutts with human eyes. Besides the urge to kill the tributes, the mutts' eyes make them even harder to deal with. The eyes on their faces are identical to the eyes of the other twenty-one tributes which are already dead. Besides, the mutts' shapes and fur are similar to the tributes' physical appearances - generating terror as Katniss realizes who each mutt is representing.

These mutations proof two important ideas: the first is that the Capitol's science is very advanced. Wolves come from the canis lupus species, of the canis

\footnotetext{
${ }^{36}$ Noel Carroll, Op. Cit., 1990, p. 23.
} 
genus and part of the carnivora order.${ }^{37}$ Humans, on the other hand, come from the homo sapiens species, being part of the homo genus and the primates order. ${ }^{38}$ Wolves and humans share the mammalia class and the eutheria subclass. ${ }^{39}$ There is no connection between these two species that could support such superior genetic engineering like the one in Collins' novel - which is not a problem, since we are talking about a dystopian future, when new technologies could be discovered.

The second idea is another confirmation of how little life means to the Capitol. Not only the tributes are murdered in the arena, but also afterwards their genetic material is used to create monstrous beasts. The Capitol denies them a future and then revokes their identities. Sharing the same principle of sacrificing some lives to achieve one's goal, Shelley's character's vision of science is noticeable: “[o]ne man's life or death were but a small price to pay for the acquirement of the knowledge which I sought, for the dominion I should acquire and transmit over the elemental foes of our race" ${ }^{40}$.

The tracker jackers are another kind of genetically engineered mutts made and controlled by the Capitol. They are larger than normal wasps and their venom can cause severe pain, strong hallucinations and, in some cases, death considering their insect-like appearance and their production of a toxin, they could also be considered monsters by Carroll's standards. ${ }^{41}$ The venom targets

\footnotetext{
${ }^{37}$ José Mariano Amabis e Gilberto Rodrigues Martho, Biologia em contexto: do universo às células vivas, 2013a, p. 91.

${ }^{38}$ Idem, Biologia em contexto: adaptação e continuidade da vida, 2013b, p. 282-283.

${ }^{39}$ Maurício Marczwski e Eduardo Vélez, Ciências Biológicas - v. 2, 1999, p. 356.

${ }^{40}$ Mary Shelley, Op. Cit., 2015, p. 15.

${ }^{41}$ Noel Carroll, Op. Cit., 1990.
} 
the region of the brain that responds to fear, driving the person who was stung to a madness condition. These mutts will track and chase down anyone who disturbs their nest or try to kill them - that is where the name tracker jackers comes from.

In the end of Catching Fire - the trilogy's second book -, the Capitol captures Peeta and then uses the tracker jackers to torture him. They use their venom to change Peeta's memories about Katniss, making him believe she is a mutt fashioned by the Capitol. Peeta can no longer tell which memories are real from the ones that were fabricated by his torturers. He starts to live in a constant state of fear. The first time Peeta sees Katniss after being released by the rebels from his captivity, he tries to kill her. This fact makes the rebels realize what the Capitol had done to Peeta. They hijacked him, which is the same as capturing or seizing.

Peeta has only one wish the night before the beginning of the Seventyfourth edition of the Games (the night before he was tossed inside an arena with twenty-tree other tributes trying to kill him): he wishes to die as himself. He does not want them - the Gamemakers, the public, the Capitol, President Snow - to transform him into a monster he has never been. And later, his wish is denied when he is hijacked. Peeta would never be the same again and he gets horrified by his reality: "I'm the monster. I'm the mutt. I'm the one Snow has turned into a weapon"42.

\footnotetext{
${ }^{42}$ Suzanne Collins, Mockingjay, 2010, p. 290.
} 
In similar agony, Frankenstein's creature responds to the details of his unnatural monster-like conception described in his creator's journal:

It was your journal of the four months that preceded my creation. You minutely described in these papers every step you took in the progress of your work; this history was mingled with accounts of domestic occurrences. You doubtless recollect these papers. Here they are. Everything is related in them which bears reference to my accursed origin; the whole detail of that series of disgusting circumstances which produced it is set in view; the minutest description of my odious and loathsome person is given, in language which painted your own horrors and rendered mine indelible. I sickened as I read. "Hateful day when I received life", I exclaimed in agony. "Accursed creator! Why did you form a monster so hideous that even you turned from me in disgust?" ${ }^{43}$.

As we mentioned, Victor's creature clearly fits Noel Carroll's monster definition - we can even see the use of the word disgust in the end of the citation above. However, is Frankenstein's creature the only monster readers can find in Mary Shelley's story? Is he the real monster of the story or does that title suits Mr. Frankenstein better? Leaving Carroll's monster explanation aside, we go back to Hansen's to try to answer these questions. She classifies

any rejection of human as monster [as] incorrect [...]. In fact, all monsters are human constructs which reflect those beings that made them. They are, in essence, psychologically not separate from humans, but mirrors for humans. The monstrous does not - and cannot - exist outside of humanity. ${ }^{44}$

\footnotetext{
${ }^{43}$ Mary Shelley, Op. Cit., 2015, p. 117-118.
}

${ }^{44}$ Michelle Kay Hansen, Op. Cit., 2009, p. 19. 
With that said, the acts of Victor Frankenstein's creature should not be analyzed without analyzing Victor's own acts, because, according to Hansen, they cannot be separated. Victor abandons his creature shortly after giving life to it. The creature never receives any orientation or affection during the whole narrative. Hence, it is incredibly lonely, even lonelier than the devil himself because he has followers, at least - this is the example given by the creature to exemplify his lonely agony-, and that is Frankenstein's fault. ${ }^{45}$

Humans are social beings and our social behavior helped us survive. A study about the consequences that loneliness can have in people's lives has shown that loneliness harmfully affects a person's quality and duration of life. ${ }^{46}$ Since Frankenstein's creature is made up of human body parts, it is logical to expect that he will have some similarities to us. Socially, as a proof of that, he tries to make contact with a French family and later he asks Frankenstein for a partner. The creature ends up receiving negative reactions in both scenarios.

So, Frankenstein not only abandons his creation but takes from him any chance he has of living a healthy life. Frankenstein does not give the creature any tools to build himself a normal life, whatever those might be in a case like this. Victor does not even bother to know if what he created would survive after being left alone just a few hours after conception. And even so, Frankenstein puts the blame of his misfortunes on his creation when he did nothing for that being's sake after it came to life. If humans can be monsters, Victor Frankenstein

\footnotetext{
${ }^{45}$ Mary Shelley, Op. Cit., 2009, p. 118.

${ }^{46}$ John T. Cacioppo e Stephanie Cacioppo, Social relationships and heath: the toxic effects of perceived social isolation, 2014.
} 
definitely looks like one. His creature is just another form through which his monstrosity took shape.

In The Hunger Games, during the first rebellion, genetically modified male birds capable of memorizing and repeating entire human conversations are created. They are called jabberjays. The Capitol sends them to the districts to record the rebels' plans and then report all the information they gathered. The rebels, however, soon understand what is happening and use the jabberjays to send incorrect intelligence to the Capitol. When the Capitol becomes aware of what the rebels are doing, they set the jabberjays free to die in nature - so they abandon their creation just like Frankenstein does.

Furthermore, the jabberjays are used by the Capitol inside the Seventyfifth edition arena to torture Katniss and Finnick in one of the clock sections. The jabberjays are programmed to repeat desperate cries for help using the voices of the tributes' loved ones. Through the third novel, Katniss makes a statement about mutts:

No mutt is good. All are meant to damage you. Some take your life, like the monkeys. Others your reason, like the tracker jackers. However, the true atrocities, the most frightening, incorporate a perverse psychological twist designed to terrify the victim. The sight of the wolf mutts with the dead tributes' eyes. The sound of the jabberjays replicating Prim's tortured screams. The smell of Snow's roses mixed with the victims' blood. Carried across the sewer. Cutting through even this foulness. Making my heart run wild, my skin turn to ice, my lungs unable to suck air. It's as if Snow's breathing right in my face, telling me it's time to die. ${ }^{47}$

${ }^{47}$ Suzanne Collins, Mockingjay, 2010, p. 311-312. 
All these mutations reaffirm that the Capitol and President Snow are truly willing to terrify the people from Panem. They exemplify the terror that rules full authority governments, as Arendt declares. ${ }^{48}$ For example, anyone who tries to go against the Capitol before the second rebellion, anyone who says or hears something that can be interpreted as a move against President Snow's rulership is transformed into an Avox. This is the name given to the people that have their tongue cut and are forced to work in the Capitol's jobs that no one else wants. Still according to Arendt, this kind of regimes cannot allow any way of power besides their own and they make that certain — as we can see in the passage below:

The decisive difference between totalitarian domination, based on terror, and tyrannies and dictatorships, established by violence, is that the former turns not only against its enemies but against its friends and supporters as well, being afraid of all power, even the power of friends. The climax of terror is reached when the police state begins to devour its own children, when yesterday's executioner becomes today's victim. ${ }^{49}$

Taking Arendt's words, nobody is safe under a supreme authority regime, neither the ones who support the command nor the torturers. In Collins' story, we can consider the Gamemakers as those torturers or executioners, and it is not a safe position. By the end of the first book, the Head Gamemaker of the Seventyfourth edition of the Hunger Games, Seneca Crane, is killed because he lets Katniss overrule the Capitol's own game, making sure both her and Peeta walk away alive from the arena:

\footnotetext{
${ }^{48}$ Hannah Arendt, Op. Cit., 1973, p. 344.

${ }^{49}$ Hannah Arendt, On Violence, 2002, p. 143.
} 
"I have a problem, Miss Everdeen," says President Snow. "A problem that began the moment you pulled out those poisonous berries in the arena."That was the moment when I guessed that if the Gamemakers had to choose between watching Peeta and me commit suicide - which would mean having no victor - and letting us both live, they would take the latter. "If the Head Gamemaker, Seneca Crane, had had any brains, he'd have you dust right then. But he had an unfortunate sentimental streak. So here you are. Can you guess where he is?" he asks.I nod because, by the way he says it, it's clear that Seneca Crane has been executed. ${ }^{50}$

The quotation above is a fragment from a conversation Katniss had with President Snow in the beginning chapters of the trilogy's second book. President Snow appears to be the personification of human monstrosity throughout the story. He uses all the tools progress gave him to create monsters and preserve his ruler status. But he is definitely not the only one who committed monstrous actions in name of the same status.

After the bombing that burns District Thirteen to the ground, the other districts believe there are no survivors, but there are. That is possible thanks to District Thirteen's underground building. The building existence was not of public knowledge. The Capitol commanders, however, knew about it and they make a political agreement to put an end to the Dark Days to prevent the start of a nuclear war — which could lead to humanity eradication this time around.

District Thirteen lost a lot in the first rebellion and the bombing but the agreement with the Capitol made it possible for them to try to rebuild their lives. They made life possible underground while the other districts subdued by the Capitol on the ground. When the second rebellion begins, District Thirteen - as

${ }^{50}$ Suzanne Collins, Mockingjay, 2010, p. 19. 
they reveal themselves to the others fighting districts - is a key player to President Snow's defeat, but not without costs.

In the course of her monster dissertation analysis, Hansen writes about the monstrous protagonist, or simply the man or woman as a monster, which is the kind of character who becomes the very monster they are trying to defeat. ${ }^{51}$ Through the second rebellion, District Thirteen was governed by President Coin, who runs her district with very strict rules. Because of the district's fundamental support during the rebellion, it was expected that she would take Snow's place by the end of the conflict.

However, in order to achieve her goal of taking Snow's place, Coin makes a decision that leads Katniss' sister and more innocents to being firebombed and killed. President Snow, as planned by Coin, was blamed for that move. And this is the main decision that makes Coin another important figure of human monstrosity; her hunger for power makes her act towards her objective without considering the damage that could be caused to others. She is the monstrous character who turned out to be a monster just like Snow.

\section{Final messages}

As already exemplified, Shelley's and Collins' works share a negative view towards the progress of science and its consequences on human societies, and in addition they might share the same final message. In the quote below, Victor Frankenstein talks about how the knowledge obtained from scientific discoveries

${ }^{51}$ Michelle Kay Hansen, Op. Cit., 2009, p. 94. 
led to his own destruction and misery, coming to the conclusion that the ones without such ambition and who live life in a simpler manner are indeed the happiest ones:

I will not lead you on, unguarded and ardent as I then was, to your destruction and infallible misery. Learn from me, if not by my precepts, at least by my example, how dangerous is the acquirement of knowledge and how much happier that man is who believes his native town to be the world, than he who aspires to become greater than his nature will allow. ${ }^{52}$

Similarly, Katniss Everdeen - Collins' heroine - divagates on how life would be better if the Games or the Capitol did not exist; a place where the lullaby Deep in the meadow would be true and Peeta's children would be safe. ${ }^{53}$ The lullaby talks about a place where nature is back on focus, where people are safe to live and to love. Moreover, the lyrics imply that the elements of nature are keeping the danger and troubles away. ${ }^{54}$ And, confirming Collins' message, in the epilogue of the last book of the trilogy, Katniss and Peeta's family is playing in the meadow.

Furthermore, we can take another message from both narratives. After the war is over and Katniss is coming back to her home (the former District Twelve), she talks to Plutarch Heavensbee (a former Gamemaker, as already stated) about the inclination to self-destruction humans have:

\footnotetext{
${ }^{52}$ Mary Shelley, Op. Cit., 2015, p. 40.

${ }^{53}$ Suzanne Collins, Catching Fire, 2009, p. 330.

${ }^{54}$ Idem, The Hunger Games, 2008, p. 230-231.
} 
[...] The truth is, no one quite knows what to do with me now that the war's over, although if another one should spring up, Plutarch's sure they could find a role for me. Then Plutarch has a good laugh. [...] "Are you preparing for another war, Plutarch?" I ask. "Oh, not now. Now we're in that sweet period where everyone agrees that our recent horrors should never be repeated," he says. "But collective thinking is usually short-lived. We're fickle, stupid beings with poor memories and a great gift for selfdestruction. ${ }^{55}$

Plutarch affirms humans tend not to remember the horrors of a war, engaging in new ones after some time in History. He suggests that, if another war does not occur in the future, the human race may be finally evolving. This statement implies humans still live without actual logic thinking; on the contrary, we live by following primitive impulses. Collins' character also talks about how fragile collective thinking is, implying that, at any moment, it can come to ruins, guided by one's selfness. And these affirmations may be the result of humans' selfish, non-rational, primitive urge for power - which also leads to scientific discoveries like Frankenstein's.

Correspondingly, Victor Frankenstein can exemplify all of Plutarch's assertions. Victor was motivated by his desire to achieve knowledge from the secrets of the world. He does not justify his search rationally, but lets the reader thinking it was something he had to do because he fiercely wanted to do it or needed to do it. ${ }^{56}$ Frankenstein does not take any responsibilities for the consequences of discovering the power of creation and then misguidedly

\footnotetext{
${ }^{55}$ Suzanne Collins, Mockingjay, 2010, p. 379.

${ }^{56}$ Mary Shelley, Op. Cit., 2015, p. 195.
} 
creating an entirely new creature. Instead, he keeps blaming anyone else but himself, until he is on his deathbed.

Although Victor says people should learn the dangers of the acquirement of knowledge from his example, in his last words he contradicts himself by saying:

Seek happiness in tranquility and avoid ambition, even if it be only the apparently innocent one of distinguishing yourself in science and discoveries. Yet why do I say this? I have myself been blasted in these hopes, yet another may succeed. ${ }^{57}$

While Frankenstein had his own war trying to kill his creature after the murderers of his loved ones, the last quote demonstrates he would do it all again for the chance of succeeding, as should others. These words can also indicate Shelley's view that the search for knowledge and power through science is in the human nature as many other primitive instincts.

\section{Conclusion}

The purpose of this article was to point out scientific and technological progress pessimism found through the reading of Frankenstein and The Hunger Games trilogy, their monsters' characterization, and some possible similarities between both stories. The pessimistic view towards progress was supported by

${ }^{57}$ Ibidem, p. 202. 
Walter Benjamin's theoretical work, essentially his metaphor on the catastrophic consequences progress can have - as we confirm in Shelley's and Collins' stories.

We also based our work on Hannah Arendt's asserts about what terror supreme authority regimes are based on and how they use the tools progress provides to keep themselves in command. We applied her work on the analyses of how the dystopian world of Panem was governed by President Snow. We concluded that this kind of governments, using Michelle Kay Hansen's monster definition, can be considered monstrous and so can humans - especially those in charge of these institutions.

According to Hansen's ideas, all monsters are mirrors for humanity ${ }^{58}$ - so, in that case, there is no monster without humans. Considering that point of view, we came to the conclusion that Victor Frankenstein's creature is in fact a part of the prior monster which is Frankenstein himself. Scientific progress helps Mr. Frankenstein to give form to his monstrous side, guided by ambition and need for power. These feelings make him blame the thing he creates but never himself for the results of his primary act.

President Snow and President Coin are personifications of humans as monsters in Collins' trilogy. Led by the same instincts (ambition and the need for power) than those that influenced Frankenstein's actions, both Presidents make use of the tools that are in their disposal to assure their regimes. And by doing so, they leave a pile of children bodies and catastrophe behind.

${ }^{58}$ Michelle Kay Hansen, Op. Cit., 2009. 
Therefore, Collins' characters and Frankenstein exemplify Shelley's warning about the outcome misguided knowledge can lead to. Both stories, however, provide an alternative fate for humanity: if you can, do not let your ambitious instinct get the best of you; preserving nature and simple life would represent a chance for humans of not extinguishing themselves because of what we call progress.

\section{References}

ALDISS, Brian. Billion Year Spree: the true history of science fiction. New York: Doubleday, 1973.

AMABIS, José Mariano; MARTHO, Gilberto Rodrigues. Biologia em contexto: do universo às células vivas. São Paulo: Moderna, 2013a.

AMABIS, José Mariano; MARTHO, Gilberto Rodrigues. Biologia em contexto: Adaptação e continuidade da vida. São Paulo: Moderna, 2013b.

ARENDT, Hannah. The Origins of Totalitarianism. Orlando: Harcourt, 1973.

ARENDT, Hannah. On Violence. In: HAUGAARD, Mark (Org.). Power: a reader. Manchester: Manchester University Press, 2002.

BENJAMIN, Walter. A obra de arte na época da sua reprodutibilidade técnica. In: BENJAMIN, Walter. Magia e técnica, arte e política - ensaios sobre literatura e história da cultura. Obras escolhidas, volume I. São Paulo: Editora Brasiliense, 1985. 
BENJAMIN, Walter. Sobre o conceito da História. In: BENJAMIN, Walter. Magia e técnica, arte e política - ensaios sobre literatura e história da cultura. Obras escolhidas, volume I. São Paulo: Editora Brasiliense, 1985.

CACIOPPO, John T.; CACIOPPO, Stephanie. Social relationships and health: the toxic effects of perceived social isolation. Social and personality physiology compass, New Jersey, v. 8, n. 2, p. 58-72, fev. 2014.

CARROLL, Noel. The philosophy of horror or paradoxes of the heart. New York: Routledge, 1990.

COLLINS, Suzanne. The Hunger Games. New York: Scholastic Press, 2008.

COLLINS, Suzanne. Catching Fire. New York: Scholastic Press, 2009.

COLLINS, Suzanne. Mockingjay. New York: Scholastic Press, 2010.

HANSEN, Michelle Kay. Monsters in our midst: an examination of human monstrosity in fiction and film of the United States. 2012. 165f. Dissertation (Doctor of Philosophy in English) - Department of English, University of Nevada, Las Vegas, NV.

KAVADLO, Jesse. American popular culture in the era of terror: falling skies, dark knights rising, and collapsing cultures. Santa Barbara: ABC-CLIO, LCC, 2015.

LE GUIN, Ursula K. Introduction. In: LE GUIN, Ursula K. The Left Hand of Darkness. New York: Ace Books, 2010.

MARCZWSKI, Maurício; VÉLEZ, Eduardo. Ciências Biológicas. São Paulo: FTD, 1999. 
MCCLANTOC, Keshia. Welcome to the Arena: Deconstructing the Female Character in Dystopian Literature. Proceedings of the National Conference on Undergraduate Research (NCUR) 2016. University of North Carolina Asheville, p. 510-517, 2016.

NORDHAUS, William D. The Economics of New Goods. Chicago: University of Chicago Press, 1996.

RADCLIFFE, Ann. On the Supernatural in Poetry. The New Monthly Magazine, London, v. 16, n. 1, p. 145-152, 1826.

SHELLEY, Mary. Frankenstein. New York: Barnes \& Noble, 2015.

SHELLEY, Mary. Introduction. In: SHELLEY, Mary. Frankenstein. New York: Barnes \& Noble, 2015.

\section{Referência para citação deste artigo}

BENEDITO, Andressa Carolina dos Santos; TARRAN, Fernanda Martinez. Pessimism and monstrosity: a comparative analysis between Frankenstein and The Hunger Games. Revista PHILIA | Filosofia, Literatura \& Arte, Porto Alegre, volume 2, número 1, p. 26 - 57, junho de 2020. 